(c) American Dairy Science Association, 2003.

\title{
The Association Between Milk Urea Nitrogen and DHI Production Variables in Western Commercial Dairy Herds ${ }^{1}$
}

\author{
R. G. Johnson and A. J. Young \\ Department of Animal, Dairy, and Veterinary Sciences, Utah State University, Logan 84322
}

\begin{abstract}
A retrospective observational study was conducted using data from Dairy Herd Improvement monthly tests to investigate the association between milk urea nitrogen (MUN) concentration and milk yield, milk protein, milk fat percentage, SCC, and parity for commercial Holstein and Jersey herds in Utah, Idaho, and Montana. Mean MUN for Holstein cows was $15.5 \mathrm{mg} /$ $\mathrm{dl}(5.5 \mathrm{mmol} / \mathrm{L}) \mathrm{MUN}$ and $14.1 \mathrm{mg} / \mathrm{dl}(5.0 \mathrm{mmol} / \mathrm{L})$ for Jersey cows. Mean MUN, categorized by 30-d increments of days in milk (DIM), paralleled changes in milk values and followed a curvilinear shape. For Holstein cows, concentrations of MUN were different among lactation groups 1, 2, and 3+ for the first 90 DIM for Holsteins. Overall, concentrations of MUN were lower during for the first 30 DIM compared with all other DIM categories for both Holstein and Jersey cows. Multivariate regression models of MUN by milk protein showed that as the milk protein percentage increased, MUN concentration decreased; however, models for Jersey cows showed that MUN did not decrease significantly until above $3.4 \%$ milk protein. Milk fat percentage also decreased as MUN increased, but by only $1 \mathrm{mg} / \mathrm{dl}$ MUN over the range of 2.2 to $5.8 \%$ milk fat. Somatic cell count showed a negative relationship with MUN. Holstein cows with milk protein percentage $>3.2 \%$ had lower MUN compared with cows having milk protein $<3.2 \%$ for milk yields from 27.3 to $54.5 \mathrm{~kg} / \mathrm{d}$ and lower than cows having a milk protein $<3.0 \%$ for milk yield of 54.5 to $63.6 \mathrm{~kg} / \mathrm{d}$. In Jersey cows, MUN concentrations were not different among milk protein percentage categorized by milk yield. This study found that MUN was inversely associated with milk protein percentage and paralleled change in milk yield over time.
\end{abstract}

(Key words: milk urea nitrogen, milk protein, milk fat, Dairy Herd Improvement)

\footnotetext{
Received July 8, 2002.

Accepted April 25, 2003.

Corresponding author: A. J. Young; e-mail: alleny@ext.usu.edu.

${ }^{1}$ This research was supported by the Utah Agricultural Experiment Station, Utah State University, Logan, Utah 84322-4810. Approved as journal paper no. 7491 .
}

Abbreviation key: NUE $=\mathrm{N}$ utilization efficiency, $\mathbf{U N}=$ urinary $\mathbf{N}$.

\section{INTRODUCTION}

Milk urea nitrogen is a rapid noninvasive tool to estimate urinary nitrogen (UN) excretion in dairy cows (Jonker et al., 1998). High concentrations of urea in the blood and milk can result from excess dietary protein (Baker et al., 1995; Broderick and Clayton, 1997) that can lead to excess UN, which can have a negative environmental impact (Kohn et al., 1997). It has been reported that protein efficiency (milk protein/ feed protein consumed) of dairy cows can be improved by various feeding strategies and dietary manipulations (Baker et al., 1995; Vagnoni and Broderick, 1997; Mackle et al., 1999).

Jonker et al. (2002) found that $40 \%$ of Maryland and Virginia dairy farmers did not know what MUN was, and $89.5 \%$ did not routinely run the test. However, after participating in a field study, those farmers who participated found the MUN test to be useful and resulted in changed behaviors. The associations between MUN, nitrogen utilization efficiency (NUE), and milk variables would be important, from a practical aspect, in helping farmers understand how nutritional decisions can impact economic and environmental factors.

Several studies have evaluated the relationship between MUN and production variables in commercial dairy herds. Godden et al. (2000b) reported a positive relationship between herd-level average MUN and dietary variables such as CP, RDP, RUP and a negative association with nonfiber carbohydrates. In a related paper, Godden et al. (2000a) found a positive nonlinear association between cow-level MUN and milk yield and a negative nonlinear association between MUN and milk fat and protein percentage and a significant negative nonlinear association with somatic cell linear score. Other researchers have also found a positive relationship between MUN and milk yield (Carlsson et al., 1995), whereas others have found a negative relationship (Broderick and Clayton, 1997). Eicher et al. (1999) found the associations between MUN or milk protein percentage with respect to production factors such as parity, milk yield, and DIM varied consider- 
ably among herds. Carlsson and Bergström (1994) reported that increased milk fat percentage could have a negative effect on measured MUN.

Dairies in the Intermountain West utilize high protein legume forages in rations (Sannes, 2000) and the association between NUE and production variables, as measured by MUN, would be useful in helping minimize nitrogen losses while maintaining production.

The objective of this study was to characterize and investigate the association between MUN and milk yield, milk protein, milk fat, SCC, DIM, and parity in Holstein and Jersey cows using DHI records from commercial dairies located in the Intermountain West.

\section{MATERIALS AND METHODS}

A retrospective, observational study was conducted by analyzing individual cow records from monthly DHI tests collected by the Rocky Mountain DHI affiliate (Logan, UT). Forty-one herds (75.5\% of cows) were from Utah, 6 (12.4\% of cows) from Idaho, and 7 (12.1\% of cows) from Montana. Monthly herd milk tests beginning January 1999 and ending December 2000, that included a MUN test, were combined into a dataset that included herd code, date of test, breed of cow, milk weight, milk fat percentage, milk protein percentage, SCC, MUN, parity, DIM, breeding date and pregnancy status. A total of 49 Holstein and 5 Jersey herds were included, with each herd being represented by 3 to 19 monthly tests during the 24-mo period. Herd sizes ranged from 40 to 550 cows. Open free-stall housing and TMR feeding were the most common management practices on these farms, but no distinction was made for management style or feeding scheme in the data set. Missing values were coded as such in the database and each production variable was screened for outliers. Milk urea $\mathrm{N}$ concentrations $<1$ or greater than $40 \mathrm{mg} / \mathrm{dl}$ were excluded from the analysis to remove outliers and because there were too few values. Cows with milk production greater than $84 \mathrm{~kg}$ were also excluded. The complete dataset consisted of 69,724 Holstein and 6136 Jersey individual cow-month records.

The milk sample used for component analysis was from either one or two milkings and no distinction was made in the database regarding milk sampling because most herds were fed TMR. For herds where only one sample was taken each month, a.m. and p.m. samplings were normally alternated each month so that the MUN analysis probably wasn't biased in any particular direction. Milk was analyzed for milk fat and protein percentage and SCC using the infrared method (Bentley 2000; Bentley Instruments, Chaska, $\mathrm{MN})$. Concentrations of MUN were determined using the Bentley Instruments Chemspec 150 Urea analyzer (Chaska, MN) for milk. This machine uses a chemical reaction to determine MUN concentrations rather than the NIR method. Urea was measured by an enzymatic reaction (modified Berthelot reaction) that splits urea to ammonia that is quantified colormetrically.

\section{Statistical Analyses}

Categories. Days in milk were grouped into 30-d increments, with those greater than $420 \mathrm{~d}$ grouped into one category. Milk urea $\mathrm{N}$ was grouped by increments of $2 \mathrm{mg} / \mathrm{dl}$ with those less than or equal to 6 $\mathrm{mg} / \mathrm{dl}$ grouped into one category, and equal to or greater than $24 \mathrm{mg} / \mathrm{dl}$ as a category. Milk production was grouped by increments of $9.1 \mathrm{~kg} / \mathrm{d}(20 \mathrm{lb} / \mathrm{d})$ with the upper grouping for Jersey cows of $45.5 \mathrm{~kg}$ and greater and $63.6 \mathrm{~kg}$ and greater for Holstein cows.

Milk protein percentages were grouped into categories in two different ways. In the first, milk protein percentage was categorized into increments of $0.2 \%$ beginning with $\leq 2.2 \%$ and ending with $\geq 4.8 \%$. In the second set, milk protein categories were created based on the groupings in Nelson, 1996. For Holsteins, the categories were $\leq 3.0 \%, 3.01$ to $3.2 \%$, and $>3.2 \%$ milk protein. Although no breakdown has been suggested for Jersey cows, we categorized them in a similar manner using the following groupings: $\leq 3.5 \%, 3.51$ to $3.7 \%$, and $>3.7 \%$ milk protein.

Descriptive statistics. Descriptive statistics were computed for DIM, milk yield, MUN, milk protein and fat percentage, SCC and parity, by breed of cow, using the Proc Freq procedure of SAS (SAS, 1996).

Simple correlation coefficients and principal component analyses were calculated to determine collinearity (SAS, 1996). Variables correlated at $r>0.5$ were not included in the same model. Least squares means were determined for MUN concentration and milk yield by DIM categories for Holstein and Jersey cows using the Proc Mixed procedure in SAS (SAS, 1996). Parity, DIM, and test month within test year were added to the model as covariates. Cow within herd was included in the random statement to control for repeated measures within herd on different test days.

Association between MUN categories and production variables. Multivariate mixed linear regression models using the Proc Mixed procedure in SAS (SAS, 1996) were used to determine the association between milk yield, milk fat and protein percentage, SCC, linear SCC, pounds of fat and protein per day (dependent variables) and MUN categories (independent variable). Parity, DIM, and month of test within year of test were added to the model as covariates. Test month within test year was added to make allow- 
ance for the change from total milk protein to true milk protein during the time period of data collection. The reported values are primarily true protein. Leastsquares means were determined for Holstein and Jersey breeds of cow. Cow within herd was included in the random statement to control for repeated measures within herd on different test days.

Association between MUN concentrations and DIM and parity. Multivariate mixed linear regression models using the Proc Mixed procedure in SAS (SAS, 1996) was used to determine the association between MUN (dependent variable) and DIM and parity categories (independent variables). Test month within test year was added to the model as a covariate. Least squares means were calculated by breed of cow. Multiple comparisons were made with $P$-values adjusted using Tukey's procedure. Cow within herd was added to the random statement to control for repeated measures within herd on different test days.

Association between MUN and milk protein and fat percentage. A mixed multivariate regression model (Proc Mixed procedure in SAS, 1996) was developed to determine the association between MUN (dependent variable) and either milk fat or protein (independent variables). Parity, DIM, and test month within test year were added to the model as covariates. Cow within herd was added to the random statement to control for repeated measures within herd on different test days. Quadratic and cubic terms were added and remained in the model if significant $(P<0.05)$. The resulting regression equation was used to plot MUN concentration, by breed, based on a range of milk fat and protein percentages. Fat percentages greater than $5.4 \%$ for Holstein cows and less than $2.8 \%$ for Jersey cows were retained for completeness even though they are probably at the extreme ends of the range of normal values for these breeds.

Association between MUN and combinations of milk yield and milk protein percentage categories. Multivariate mixed linear regression models using the Proc Mixed procedure in SAS (SAS, 1996) was used to determine the association between MUN (dependent variable) and milk yield and protein categories (Nelson, 1996)(independent variables). Parity, DIM (not significant) and test month within test year were added to the model as covariates. Cow within herd was added to the random statement to control for repeated measures within herd on different test days. Least squares means were calculated by breed of cow. Multiple comparisons were made with $P$-values adjusted using Tukey's procedure.

\section{RESULTS AND DISCUSSION Characterization of Database}

Descriptive statistics for DHI variables are listed, by breed, in Table 1. Mean DIM was 194 for Holsteins
Table 1. Least squares means and SD of DHI variables for Holstein ( $\mathrm{n}=69,717$ cow-months) and Jersey cows $(\mathrm{n}=6138$ cow-months $)$.

\begin{tabular}{lccccc}
\hline & \multicolumn{2}{c}{ Holstein cows } & & \multicolumn{2}{c}{ Jersey cows } \\
\cline { 2 - 3 } \cline { 6 - 6 } & LS mean & SD & & LS mean & SD \\
\hline DIM & 194 & 129.0 & & 180 & 130.3 \\
Milk, kg & 33.8 & 10.73 & & 22.4 & 7.2 \\
MUN, mg/dl & 15.5 & 3.73 & & 14.1 & 3.20 \\
Protein, \% & 3.19 & 0.379 & & 3.70 & 0.447 \\
Fat,\% & 3.56 & 0.757 & & 4.62 & 0.839 \\
SCC, $\times 1000$ & 270 & 741.0 & & 336 & 909.0 \\
Linear score & 2.57 & 2.11 & & 2.88 & 2.11 \\
Parity & 2.46 & 1.60 & 2.41 & 1.66 \\
\hline
\end{tabular}

and 180 for Jerseys and was higher than reported in other studies (Jonker et al., 1998; Godden et al., 2001a). Milk yield for Holsteins, $33.8 \mathrm{~kg}$, was higher than has been reported in other MUN studies (Carlsson et al., 1995; Godden et al., 2001a, 2001b). Overall, average cow-level MUN concentrations were similar to values reported in other studies (Broderick and Clayton, 1997; Jonker et al., 1998; Godden et al., 2001a; Rajala-Schultz et al., 2001).

Mean milk fat and protein percentages for Holsteins were 3.56 and $3.19 \%$, respectively, and were similar to values reported by Jonker et al. (1998) and Oltner and Wiktorsson (1983), but lower than those reported by Godden et al. (2001a). Mean milk fat and protein percentages were 4.62 and $3.70 \%$ for Jersey cows. As expected, mean milk yield was higher for Holstein cows $(P<0.001)$ than for Jersey cows, and both mean milk protein and fat percentages were higher in Jersey cows $(P<0.001)$. The mean parity for both breeds was 2.4 lactations and is similar to what was reported by Godden et al. (2001a).

\section{Associations Between MUN and DIM}

Mean milk yield and MUN concentrations, by DIM categories, demonstrated curvilinear, parallel relationships (Figures 1 and 2; Tables 2 and 3). The concentration of MUN was lower $(P<0.0001)$ during the first 30 DIM category compared with all other DIM categories. Others have shown this same association (Carlsson et al., 1995; Eicher et al., 1999; Godden et al., 2001a). Although it can be speculated that the lower MUN concentrations might be related to lower DMI or possibly consumption of a ration with a different composition than after 30 DIM, further work to determine the cause of the lower MUN during this time period would be helpful when using MUN concentrations as a management tool.

Carlsson et al. (1995) observed higher urea concentrations at peak lactation than in later lactation, similar to this study. Jonker et al. (1999) modeled expected 


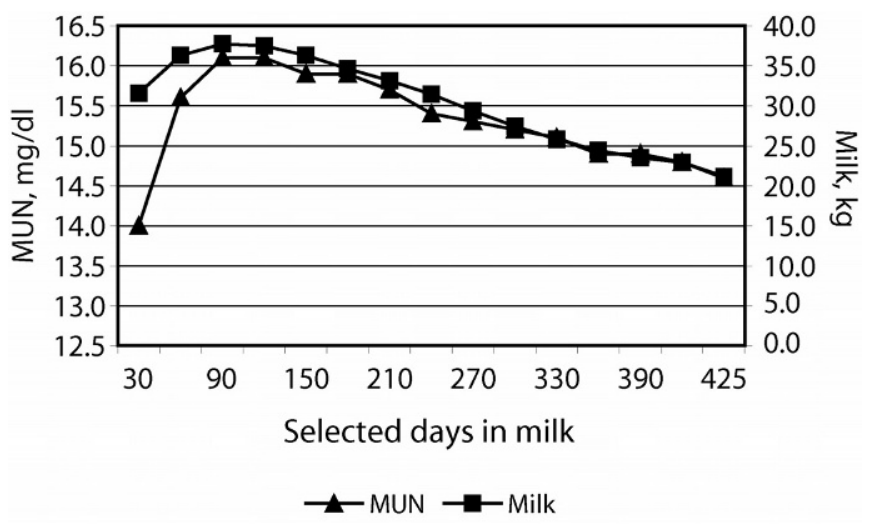

Figure 1. Least squares means of MUN concentration and milk yield by 30 -d DIM categories for Holstein cows.

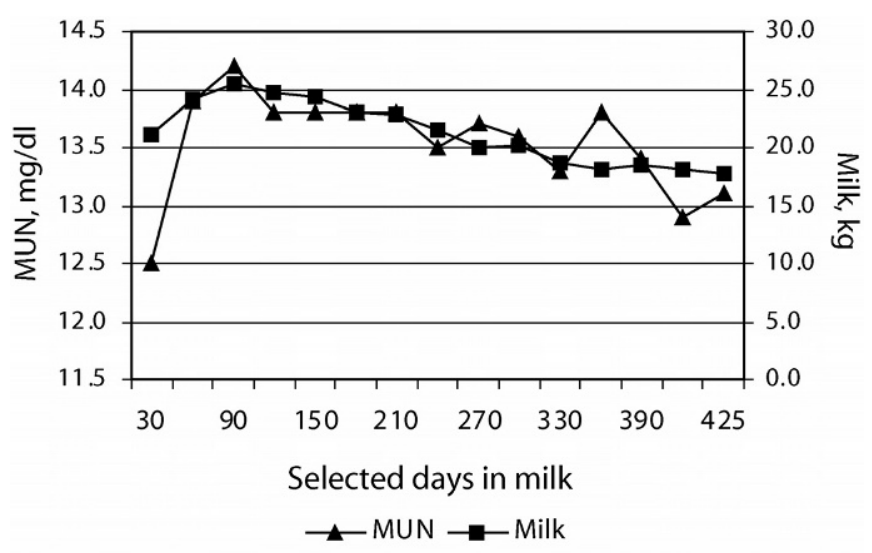

Figure 2. Least squares means of MUN concentration and milk yield by 30-d DIM categories for Jersey cows.
MUN concentrations for an entire lactation and showed that MUN concentrations resembled a lactation curve. Schepers and Meijer (1998) found that DIM had no effect on mean MUN. However, the authors stated that because the nutritional variables they looked at were not statistically independent, the effect of DIM was probably included indirectly through the nutritional factors.

In later lactation, as milk production declines, the protein requirement decreases, and we suggest that MUN should also decline. We observed that as milk declined, some of the herd MUN concentrations did not decline at the same rate (data not shown). This suggests the possibility that for those herds, protein may have been overfed in late lactation or the ration contained a different amount of rumen degradable protein than earlier in lactation.

Godden et al. (2001a) and, to a lesser extent, Carlsson et al. (1995), showed a positive relationship between milk yield and MUN. We saw the same relationship in our data. The question then becomes one of whether changes in MUN concentrations during lactation are a function of DMI or directly associated in some manner with milk yield (Figures 1 and 2). Jonker et al. (1999) suggested that milk production drives the requirement for $\mathrm{N}$ in lactating cows fed according to NRC requirements (NRC, 2001) and that changes in total protein intake (Broderick and Clayton, 1997; Godden et al., 2001b), coupled with DMI, drive changes in MUN concentrations.

\section{Association Between MUN and Parity}

Mean MUN concentration, by DIM categories and parity, are shown for Holstein and Jersey cows in Ta-

Table 2. Least squares means of MUN concentration by DIM categories and parity for Holstein cows.

\begin{tabular}{|c|c|c|c|c|c|c|c|c|}
\hline \multirow[b]{2}{*}{ DIM category } & \multicolumn{2}{|c|}{ Lactation 1} & \multicolumn{2}{|c|}{ Lactation 2} & \multicolumn{2}{|c|}{ Lactation 3+ } & \multicolumn{2}{|c|}{ All } \\
\hline & $\mathrm{N}$ & Mean & $\mathrm{N}$ & Mean & $\mathrm{N}$ & Mean & $\mathrm{N}$ & Mean \\
\hline$\leq 30$ & 1809 & $13.6^{\mathrm{b}}$ & 1435 & $15.0^{\mathrm{a}}$ & 2137 & $13.9^{\mathrm{b}}$ & 5381 & 14.2 \\
\hline $31-60$ & 2047 & $15.6^{\mathrm{b}}$ & 1669 & $16.4^{\mathrm{a}}$ & 2478 & $15.7^{\mathrm{b}}$ & 6194 & 15.9 \\
\hline $61-90$ & 1893 & $16.2^{\mathrm{f}}$ & 1591 & $16.6^{\mathrm{e}}$ & 2402 & $16.1^{\mathrm{f}}$ & 5886 & 16.3 \\
\hline $91-120$ & 2060 & 16.3 & 1576 & 16.4 & 2313 & 16.2 & 5949 & 16.3 \\
\hline $121-150$ & 2002 & 16.1 & 1603 & 16.2 & 2258 & 16.0 & 5863 & 16.1 \\
\hline $151-180$ & 2032 & 16.2 & 1498 & 16.1 & 2193 & 15.9 & 5723 & 16.1 \\
\hline $181-210$ & 1997 & 16.0 & 1484 & 15.7 & 2142 & 15.7 & 5623 & 15.8 \\
\hline $211-240$ & 1968 & 15.7 & 1444 & 15.5 & 2079 & 15.4 & 5491 & 15.5 \\
\hline $241-270$ & 1896 & $15.6^{\mathrm{e}}$ & 1393 & $15.2^{\mathrm{f}}$ & 2007 & $15.3^{\mathrm{ef}}$ & 5296 & 15.3 \\
\hline $271-300$ & 1637 & 15.5 & 1219 & 15.2 & 1811 & 15.2 & 4667 & 15.3 \\
\hline $30-330$ & 1437 & 15.4 & 941 & 14.9 & 1392 & 15.0 & 3770 & 15.1 \\
\hline $331-360$ & 1064 & 15.3 & 743 & 14.8 & 1065 & 14.9 & 2872 & 15.0 \\
\hline $361-390$ & 745 & 15.2 & 527 & 14.8 & 763 & 14.8 & 2035 & 14.9 \\
\hline $391-420$ & 559 & 15.2 & 355 & 14.6 & 526 & 14.6 & 1440 & 14.8 \\
\hline$>420$ & 1512 & 14.8 & 701 & 14.3 & 1314 & 14.6 & 3527 & 14.6 \\
\hline Total/avg. & 24,658 & $15.5^{\mathrm{c}}$ & 18,179 & $15.4^{\mathrm{f}}$ & 26,880 & $15.3^{\mathrm{a}}$ & 69,717 & \\
\hline
\end{tabular}

${ }^{\mathrm{a}, \mathrm{b}, \mathrm{c}}$ Least square means within the same row with different superscripts differ at $P<0.0001$.

e,f,g Least square means within the same row with different superscripts differ at $P<0.05$. 
Table 3. Least squares means of MUN concentrations by DIM categories and parity for Jersey cows.

\begin{tabular}{|c|c|c|c|c|c|c|c|c|}
\hline \multirow[b]{2}{*}{ DIM category } & \multicolumn{2}{|c|}{ Lactation 1} & \multicolumn{2}{|c|}{ Lactation 2} & \multicolumn{2}{|c|}{ Lactation $3+$} & \multicolumn{2}{|c|}{ All } \\
\hline & $\mathrm{N}$ & Mean & $\mathrm{N}$ & Mean & $\mathrm{N}$ & Mean & $\mathrm{N}$ & Mean \\
\hline$\leq 30$ & 312 & $12.8^{\mathrm{ab}}$ & 140 & $13.5^{\mathrm{a}}$ & 177 & $12.1^{\mathrm{b}}$ & 629 & 12.8 \\
\hline $31-60$ & 280 & 14.1 & 170 & 14.4 & 219 & 13.9 & 669 & 14.2 \\
\hline $61-90$ & 227 & 14.8 & 140 & 14.9 & 237 & 14.3 & 604 & 14.7 \\
\hline $91-120$ & 203 & 13.8 & 139 & 14.4 & 208 & 14.6 & 550 & 14.3 \\
\hline $121-150$ & 189 & 14.1 & 113 & 14.6 & 185 & 14.3 & 487 & 14.3 \\
\hline $151-180$ & 142 & 14.1 & 131 & 14.5 & 193 & 14.2 & 466 & 14.3 \\
\hline $181-210$ & 146 & 14.0 & 108 & 14.3 & 181 & 14.2 & 435 & 14.2 \\
\hline $211-240$ & 153 & 13.5 & 114 & 14.1 & 175 & 14.1 & 442 & 13.9 \\
\hline $241-270$ & 132 & 14.5 & 101 & 14.2 & 153 & 13.9 & 386 & 14.2 \\
\hline $271-300$ & 144 & 14.2 & 74 & 13.3 & 136 & 13.9 & 354 & 13.8 \\
\hline $301-330$ & 125 & 13.9 & 83 & 13.4 & 113 & 13.2 & 321 & 13.5 \\
\hline $331-360$ & 111 & 14.2 & 42 & 13.8 & 85 & 13.9 & 238 & 14.0 \\
\hline $361-390$ & 85 & 13.9 & 27 & 14.3 & 49 & 13.5 & 161 & 13.9 \\
\hline $391-420$ & 63 & 13.0 & 31 & 13.7 & 31 & 13.1 & 125 & 13.2 \\
\hline$>420$ & 116 & 13.0 & 52 & 12.8 & 103 & 13.1 & 271 & 13.0 \\
\hline & 2428 & $13.9^{\mathrm{ab}}$ & 1465 & $14.0^{\mathrm{a}}$ & 2245 & $13.8^{b}$ & & \\
\hline
\end{tabular}

a,b,c Least square means within the same row with different superscripts differ at $P<0.0001$.

e,f,g Least square means within the same row with different superscripts differ at $P<0.05$.

bles 2 and 3. For Holsteins, the overall mean for the second-parity group was higher $(P<0.0001)$ than first or third and greater parity, even though the difference was only $0.2 \mathrm{mg} / \mathrm{dl}$. Overall mean MUN concentration of Jersey cows in third and greater lactation was lower $(P<0.0001)$ than first or second lactation. The overall differences are small, and the biological significance of this observation is questionable.

Godden et al. (2001a) found significant changes, similar to our results, in MUN concentrations by parity, which were also numerically small. In a study by Carlsson et al. (1995), multiparous cows had higher MUN (14.4 mg/dl) than primiparous cows only when cows were in confinement housing rather than on pasture. Jonker et al. (1998) used models to predict changes in MUN due to parity and suggested that first lactation animals would have a higher MUN than mature animals. In another study by Jonker et al.
(1999), target MUN concentrations averaged $16.3 \mathrm{mg} /$ dl for first lactation, 16.8 for second lactation, and 16.2 for third lactation.

In the current data, differences due to parity were only found for DIM categories of $<90$ DIM (Tables 2 and 3). Most studies have looked only at primiparous compared with multiparous cows (Carlsson et al., 1995; Jonker, 1998; Godden et al., 2001a). We do not have an explanation for the differences between second and older lactation cows.

\section{Association Between MUN and Milk Protein Percentage}

Descriptive information about protein percentage, stratified by MUN category, and breed are summarized in Tables 4 and 5 . The results of a mixed multivariate regression model of MUN against selected lev-

Table 4. Least squares means and SE for milk yield, protein, and fat percentage and SCC by MUN concentration categories for Holstein cows.

\begin{tabular}{|c|c|c|c|c|c|c|c|c|c|c|c|c|c|c|c|}
\hline \multirow[b]{2}{*}{ Mun categories, mg/dl } & \multirow[b]{2}{*}{$\mathrm{N}$} & \multicolumn{2}{|c|}{ Milk } & \multicolumn{2}{|c|}{ Protein, $\%$} & \multicolumn{2}{|c|}{ Fat, $\%$} & \multicolumn{2}{|c|}{$\mathrm{SCC}$} & \multicolumn{2}{|c|}{ Linear score } & \multicolumn{2}{|c|}{ Fat, kg } & \multicolumn{2}{|c|}{ Protein, kg } \\
\hline & & Mean & $\mathrm{SE}$ & Mean & $\mathrm{SE}$ & Mean & $\mathrm{SE}$ & Mean & $\mathrm{SE}$ & Mean & $\mathrm{SE}$ & Mean & $\mathrm{SE}$ & Mean & $\mathrm{SE}$ \\
\hline$\leq 6.0$ & 190 & 30.2 & 0.67 & 3.34 & 0.024 & 3.85 & 0.055 & 468 & 53.8 & 3.26 & 0.146 & 1.11 & 0.023 & 0.98 & 0.020 \\
\hline $8.01-10$ & 3219 & 31.4 & 0.17 & 3.33 & 0.006 & 3.72 & 0.014 & 461 & 13.8 & 3.16 & 0.038 & 1.12 & 0.007 & 1.03 & 0.005 \\
\hline $10.01-12$ & 8163 & 32.3 & 0.12 & 3.28 & 0.004 & 3.61 & 0.009 & 381 & 9.3 & 2.91 & 0.025 & 1.12 & 0.005 & 1.04 & 0.004 \\
\hline 12.01 & 13,083 & 33.1 & 0.10 & 3.25 & 0.003 & 3.57 & 0.008 & 302 & 7.7 & 2.72 & 0.021 & 1.14 & 0.004 & 1.06 & 0.003 \\
\hline $14.01-16$ & 15,126 & 33.8 & 0.09 & 3.21 & 0.003 & 3.53 & 0.007 & 255 & 7.3 & 2.55 & 0.020 & 1.16 & 0.004 & 1.07 & 0.003 \\
\hline $20.01-22$ & 4535 & 36.9 & 0.15 & 3.10 & 0.005 & 3.44 & 0.012 & 172 & 11.9 & 2.12 & 0.032 & 1.24 & 0.006 & 1.13 & 0.005 \\
\hline $22.01-24$ & 2017 & 37.7 & 0.22 & 3.07 & 0.008 & 3.45 & 0.017 & 147 & 17.3 & 1.97 & 0.047 & 1.28 & 0.008 & 1.14 & 0.006 \\
\hline$>24$ & 1304 & 37.5 & 0.27 & 3.03 & 0.009 & 3.49 & 0.022 & 124 & 21.5 & 1.96 & 0.058 & 1.30 & 0.010 & 1.11 & 0.008 \\
\hline
\end{tabular}


Table 5. Least squares means and SE for milk yield, protein, and fat percentage and SCC by MUN concentration categories for Jersey cows.

\begin{tabular}{|c|c|c|c|c|c|c|c|c|c|c|c|c|c|c|c|}
\hline Mun categories, mg/dl & $\mathrm{N}$ & \multicolumn{2}{|c|}{ Milk } & \multicolumn{2}{|c|}{ Protein, $\%$} & \multicolumn{2}{|c|}{ Fat, $\%$} & \multicolumn{2}{|c|}{$\mathrm{SCC}$} & \multicolumn{2}{|c|}{ Linear score } & \multicolumn{2}{|c|}{ Fat, kg } & \multicolumn{2}{|c|}{ Protein, kg } \\
\hline$\leq 6.0$ & 21 & 18.8 & 1.43 & 3.79 & 0.082 & 5.12 & 0.168 & 216 & 198.1 & 3.42 & 0.447 & 0.94 & 0.069 & 0.72 & 0.050 \\
\hline $8.01-10$ & 366 & 20.5 & 0.35 & 3.85 & 0.020 & 4.87 & 0.041 & 522 & 48.2 & 3.57 & 0.110 & 0.98 & 0.017 & 0.77 & 0.012 \\
\hline $10.01-12$ & 1183 & 21.2 & 0.20 & 3.82 & 0.012 & 4.78 & 0.024 & 460 & 27.6 & 3.34 & 0.064 & 1.00 & 0.010 & 0.80 & 0.007 \\
\hline $12.01-14$ & 1581 & 22.0 & 0.18 & 3.76 & 0.010 & 4.62 & 0.021 & 324 & 24.2 & 2.99 & 0.056 & 1.00 & 0.009 & 0.82 & 0.006 \\
\hline $14.01-16$ & 1405 & 22.3 & 0.19 & 3.73 & 0.011 & 4.54 & 0.022 & 255 & 26.0 & 2.80 & 0.060 & 1.00 & 0.009 & 0.82 & 0.007 \\
\hline $20.01-22$ & 146 & 23.6 & 0.56 & 3.59 & 0.032 & 4.53 & 0.066 & 128 & 77.1 & 2.19 & 0.175 & 1.05 & 0.027 & 0.83 & 0.020 \\
\hline $22.01-24$ & 57 & 23.9 & 0.88 & 3.61 & 0.050 & 4.64 & 0.103 & 329 & 121.4 & 2.66 & 0.275 & 1.08 & 0.042 & 0.85 & 0.031 \\
\hline$>24$ & 36 & 21.5 & 1.12 & 3.61 & 0.063 & 4.77 & 0.129 & 241 & 151.6 & 2.09 & 0.343 & 0.96 & 0.054 & 0.76 & 0.039 \\
\hline
\end{tabular}

els of milk protein is shown in Figure 3 for Holstein and Jersey cows. The data suggest that as milk protein percentage increased, MUN concentration decreased. Because of the inverse relationship between MUN and milk protein percentage, lower MUN may be associated with a greater use of dietary $\mathrm{CP}$, leading to improved NUE. Other reports have shown either no relationship between milk protein percentage and MUN (Broderick and Clayton, 1997; multiple regression model) or a negative, nonlinear association (Godden et al., 2001a). Equations in the current study also suggest that the relationship between milk protein percentage and MUN differs between Holstein and Jersey cows at lower milk protein percentages, but follows a similar relationship at higher milk protein percentages (Figure 3).

The concentrations of MUN categorized by milk yield and milk protein categories of $\leq 3.0 \%, 3.01$ to $3.2 \%$, and $>3.2 \%$ are shown in Table 6 for Holstein cows. Categories of $\leq 9.1$ and $>63.6 \mathrm{~kg}$ of milk were considered extreme in this dataset for Holstein cows and are not shown. In Holstein cows, MUN was lower $(P<0.0002)$ when milk protein was $>3.2 \%$ (vs. $<3.0 \%)$ for milk yields ranging from 27.31 to $63.6 \mathrm{~kg}$. Also, MUN was lower for cows with milk protein $>3.2 \%$ than the grouping of 3.01 to $3.2 \%$ milk protein for milk yields ranging from 27.3 to $54.5 \mathrm{~kg} / \mathrm{d}$. Approximately
$27.3 \mathrm{~kg} / \mathrm{cow}$ per day of milk was the minimal production level before MUN differed across milk protein levels (Table 6). Because of these relationships, perhaps milk protein percentage should be considered in addition to MUN concentration as a management tool for determining if rations are properly balanced for production. The association was not seen between MUN and milk protein categories for Jersey cows, suggesting need for research to investigate why the relationship between MUN and milk protein percentage might differ for Jersey compared with Holstein cows. Because the Jersey cows in the current study were in different herds than were the Holstein cows, herd differences in feeding regimens may account for some of the breed differences.

As listed in Nelson (1996), herd-level groupings of low, average, and high milk protein percentages in combination with three levels of MUN $(<12,12$ to 16 , and $>16 \mathrm{mg} / \mathrm{dl}$ ), may give an indication of an imbalance of protein and energy in the ration. He suggested that when milk protein was 3.0 to $3.2 \%$ and MUN concentration was 12 to $16 \mathrm{mg} / \mathrm{dl}$, protein degradability fractions and net energy were most likely balanced. In this study (Table 6), cow-level mean MUN (meant to simulate a herd-level mean) for each category of milk protein percentage and milk yield was within this range for Holsteins, except when milk production was

Table 6. Least squares means and SE of MUN concentration by milk yield and protein percentage categories for Holstein cows.

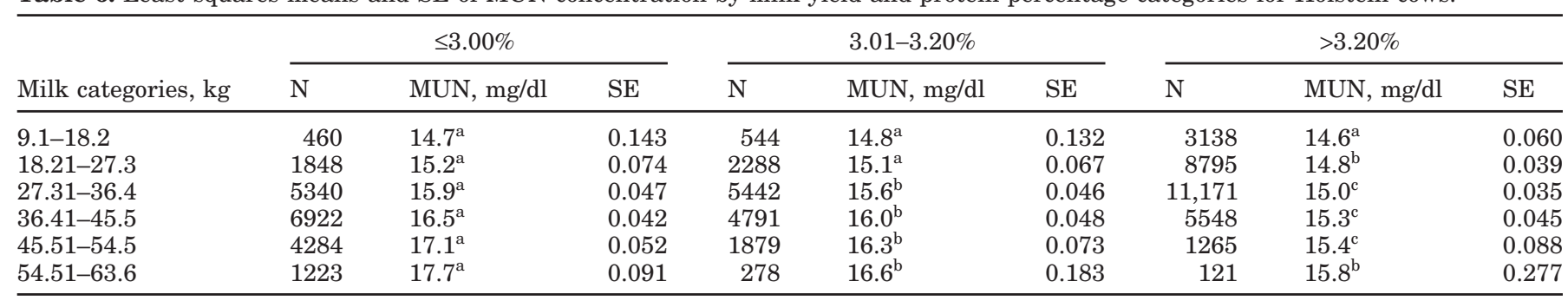

a,b,c Different within row $P<0.0002$. 


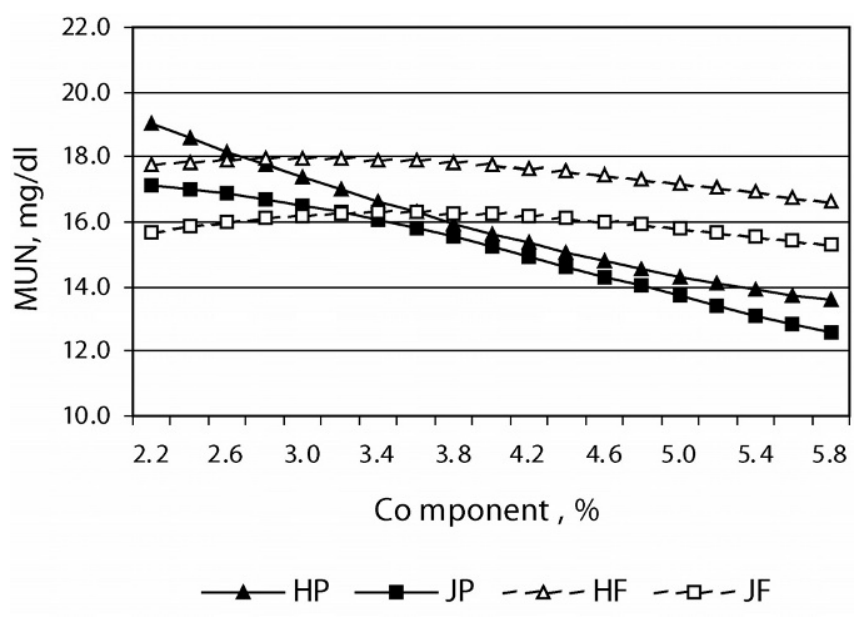

Figure 3. Graphs of the results from univariate regression models developed for the association between milk fat and protein percentage on MUN concentration for Holstein and Jersey cows (HP = milk protein percentage for Holstein cows; JP = milk protein percentage for Jersey cows; $\mathrm{HF}$ = milk fat percentage for Holstein cows; and JF $=$ milk fat percentage for Jersey cows).

very high, then MUN concentrations were higher. Kohn et al. (2002) suggested that herd-level means of 12 to $16 \mathrm{mg} / \mathrm{dl}$ may be too high. If so, then dairy farmers in the Intermountain West are possibly overfeeding protein or underestimating protein degradability of the high quality alfalfa being fed.

\section{Association Between MUN and Milk Fat Percentage}

An inverse relationship between MUN categories and milk fat percentage was observed in these data for both Holstein (Table 4) and Jersey cows (Table 5). The result of a mixed multivariate regression model of MUN against selected levels of milk fat percentage is shown in Figure 3 for Holstein and Jersey cows. Within the normal physiological range of milk fat percentages for each breed, MUN concentration change was very small, but as milk fat percentage increased MUN concentration decreased.

Godden et al. (2001a) reported a negative, nonlinear association between milk fat and MUN when cow-level analysis was performed, but when herd-level means were used (2001b), reported a positive relationship between milk fat percentage and MUN. Broderick and Clayton (1997) also reported a negative relationship between MUN and milk fat. Jonker et al. (1998) predicted that a change in milk fat of \pm 0.5 percentage units would change the estimated mean lactation MUN concentration by approximately $\pm 1.70 \mathrm{mg} / \mathrm{dl}$. The relationship between milk fat and MUN may be an indirect result of nutritional variables or a direct negative effect of milk fat on MUN (Carlsson and Bergström, 1994).

\section{Association Between MUN and SCC}

A mixed multivariate regression model of MUN with SCC showed a significant negative linear effect for both Holstein and Jersey cows (Tables 4 and 5). Godden (2001a) also reported a slightly negative relationship between MUN and linear score. Eicher et al. (1999) reported no significant association of SCC on MUN.

\section{Association Between MUN and Breed Effect}

Kauffman and St-Pierre (2001) studied the relationship between UN excretion and MUN with limited numbers of Holstein and Jersey cows. The relationship of UN to MUN was linear for both breeds, but the slopes for each breed were significantly different. It was found that the breed effect in the relationship of UN to MUN was completely eliminated when BW was included in the equation.

Jonker et al. (1998), later modified by Kohn et al. (2002), also reported a breed effect based on BW. They predicted that BW was negatively correlated with MUN concentration in lactating dairy cows. A larger cow would have a lower MUN concentration, and a smaller cow a higher MUN concentration. In this study, when breed was added to the analysis as a variable, there was a significant difference due to breed, with Jersey cows having a lower MUN concentration than the larger Holsteins (data not shown). Kauffman and St-Pierre (2001) reported no difference between Holstein and Jersey MUN concentrations (9.44 and $9.47 \mathrm{mg} / \mathrm{dl}$, respectively).

The results of the current study have shown differences within and between breeds of cows relative to MUN and other production variables. It is not clear from this dataset what caused these differences, but differing milk production and composition, different $\mathrm{N}$ utilization between the breeds, or different feeding and management strategies across herds may be included. Few other researchers have examined the differences between Holsteins and Jerseys as they relate to MUN, and this appears to be an area that needs further study.

\section{CONCLUSIONS}

In these data, MUN concentrations were positively associated with milk yield and negatively associated with milk protein and fat percentage. Milk urea $\mathrm{N}$ concentration appeared to have an inverse association 
with SCC. Our results suggest that MUN concentrations should be evaluated in association with breed, DIM, milk yield, and protein percentage when determining the efficiency of $\mathrm{N}$ utilization. Additional research on the association between production values and MUN concentration for Jersey cows is needed.

\section{REFERENCES}

Baker, L. D., J. D. Ferguson, and W. Chalupa. 1995. Reponses in urea and true protein to different feeding schemes for dairy cows. J. Dairy Sci. 78:2424-2434.

Broderick, G. A., and M. K. Clayton. 1997. A statistical evaluation of animal and nutritional factors influencing concentrations of milk urea nitrogen. J. Dairy Sci. 80:2964-2970.

Carlsson, J., and J. Bergström. 1994. The diurnal variation of urea in cow's milk and how milk fat content, storage and preservation affects analysis by a flow injection technique. Acta Vet. Scand. 35(1):67-77.

Carlsson, J., J. Bergström, and B. Pehrson. 1995. Variations with breed, age, season, yield, stage of lactation, and herd in the concentration of urea in bulk milk and individual cow's milk. Acta Vet. Scand. 36:245-254.

Eicher R., E. Bouchard, and M. Bigras-Poulin. 1999. Factors affecting milk urea nitrogen and protein concentrations in Quebec dairy cows. Prev. Vet. Med. 39:53-63.

Godden, S. M., K. D. Lissemore, D. F. Kelton, K. E. Leslie, J. S. Walton, and J. H. Lumsden. 2001a. Factors associated with milk urea concentrations in Ontario dairy cows. J. Dairy Sci. 84:107-114.

Godden, S. M., K. D. Lissemore, D. F. Kelton, K. E. Leslie, J. S. Walton, and J. H. Lumsden. 2001b. Relationships between milk urea concentration and nutritional management, production, and economic variables in Ontario dairy herd. J. Dairy Sci. 84:1128-1139.

Jonker, J. S., R. A. Kohn, and R. A. Erdman. 1998. Using milk urea nitrogen to predict nitrogen excretion and utilization efficiency in lactating dairy cows. J. Dairy Sci. 81:2681-2692.
Jonker, J. S., R. A. Kohn, and R. A. Erdman. 1999. Milk urea nitrogen target concentrations for lactating dairy cows fed according to National Research Council recommendations. J. Dairy Sci. 82:1261-1273.

Jonker, J. S., R. A. Kohn, and J. High. 2002. Use of milk urea nitrogen to improve dairy cow diets. J. Dairy Sci. 85:939-946.

Kauffman, A. J., and N. R. St-Pierre. 2001. The relationship of milk urea nitrogen to urine nitrogen excretion in Holstein and Jersey cows. J. Dairy Sci. 84:2284-2294.

Kohn, R. A., Z. Dou, J. D. Ferguson, and R. C. Boston. 1997. A sensitivity analysis of nitrogen losses from dairy farms. J. Environ. Manag. 50:417-428.

Kohn, R. A., K. F. Kalscheur, and E. Russek-Cohen. 2002. Evaluation of models to estimate urinary nitrogen and expected milk urea nitrogen. J. Dairy Sci. 85:227-233.

Mackle, T. R., D. A. Dwyer, K. L. Ingvartsen, P. Y. Chouinard, J. M. Lynch, and D. E. Bauman. 1999. Effects of insulin and amino acids on milk protein concentration and yield from dairy cows. J. Dairy Sci. 82:1512-1524.

National Research Council. 2001. Nutrient Requirements of Dairy Cattle, 7th ed., National Academy Press, Washington, DC.

Nelson, A. 1996. Practical applications of MUN analyses. Bovine Pract. 29:85-95.

Oltner, R., and H. Wiktorsson. 1983. Urea concentrations in milk and blood as influenced by feeding varying amounts of protein and energy to dairy cows. Livest. Prod. Sci. 10:457-466.

Rajala-Schultz, P. J., W. J. A. Saville, G. S. Frazer, and T. E. Wittum. 2001. Association between milk urea nitrogen and fertility in Ohio dairy cows. J. Dairy Sci. 84:482-489.

Sannes, R. 2000. The influence of ruminally degradable carbohydrates and nitrogen on microbial protein synthesis and protein efficiency of lactating Holstein cows. M.S. Thesis, Utah State Univ., Logan.

SAS/STAT: User's Guide. 1996. Version 6.12 Edition. SAS Inst., Inc., Cary, NC.

Schepers A. J., and R. G. M. Meijer. 1998. Evaluation of the utilization of dietary nitrogen by dairy cows based on urea concentration in milk. J. Dairy Sci. 81:579-584.

Vagnoni, D. B., and G. A. Broderick. 1997. Effects of supplementation of ruminally undegraded protein to lactating cows fed alfalfa hay or silage. J. Dairy Sci. 80:1703-1712. 